\title{
REVERSED VERSIONS OF ACZÉL-TYPE INEQUALITY AND BELLMAN-TYPE INEQUALITY
}

\author{
JING-FENG TIAN AND WEN-LI WANG
}

Abstract. In this note, using the method of Farid et al. (2010) [G. Farid, J. Pečarić, Atiq Ur Rehman, On Refinements of Aczél's, Popoviciu, Bellman's Inequalities and Related Results, J. Inequal. Appl. 2010 (2010), Article ID 579567], some reversed versions of Aczél-type inequality and Bellman-type inequality proposed by Farid, Pečarić and Ur Rehman are established. The obtained results are the refinements of reversed Aczél-Popoviciu inequality, Aczél-Bjelica inequality and Bellman's inequality.

Mathematics subject classification (2010): Primary 26D15; Secondary 26D10.

Keywords and phrases: Reversed version, Aczél-type inequality, Bellman-type inequality, Aczél-Popoviciu inequality, Aczél-Bjelica inequality.

\section{REFERENCES}

[1] J. ACzÉL, Some general methods in the theory of functional equations in one variable, New applications of functional equations, Uspehi. Mat. Nauk (N. S.) 11, 3 (1956), 3-68 (in Russian).

[2] R. Bellman, On an inequality concerning an indefinite form, Amer. Math. Monthly 63 (1956), 108109.

[3] M. BJeliCA, On inequalities for indefinite form, Anal. Numer. Theor. Approx. 19, 2 (1990), $105-109$.

[4] J. L. Díaz-Barrerro, M. Grau-Sánchez, P. G. Popescu, Refinements of Aczél, Popoviciu and Bellman's inequalities, Comput. Math. Appl. 56 (2008), 2356-2359.

[5] G. Farid, J. PeČArić, Atiq Ur Rehman, On Refinements of Aczél's, Popoviciu, Bellman's Inequalities and Related Results, J. Inequal. Appl. 2010 (2010), Article ID 579567, doi: 10. 1155/2010/579567.

[6] T. Popoviciu, On an inequality, Gaz. Mat. Fiz. Ser. A 11, 64 (1959), 451-461 (in Romanian).

[7] J. TiAn, Reversed version of a generalized Aczél's inequality and its application, J. Inequal. Appl. 2012 (2012): 202.

[8] P. M. VASIĆ, J. E. PEČARIĆ, On the Jensen inequality for monotone functions, An. Univ. Timişoara Ser. Şt. Matematice 17, 1 (1979), 95-104.

[9] P. M. VASić, J. E. PEČARIĆ, On Hölder and some related inequalities, Mathematica Rev. D'Anal. Num. Th. L'Approx. 25 (1982), 95-103. 